\title{
Analysis on the success factors in determining sales value of taxable object
}

\author{
Agustinus Imam Saputra*, Irwan Taufiq Ritonga \\ Faculty of Economics and Business, Universitas Gadjah Mada, Yogyakarta, Indonesia \\ ${ }^{*}$ Corresponding author email: agustinusimam.saputra@gmail.com
}

\section{A R T I C LE I N F O}

Article history:

Available online

Keywords:

SVTO, market price, best practice, isomorphism

DOI:

https://doi.org/10.20885/jaai.vol24.is $\underline{\text { s.art1 }}$

\section{A B S T R A C T}

This study aims to examine the contradiction in determining Sales Value of Taxable Object (SVTO) in accordance with fair market price in Bantul Regency and Yogyakarta City. This study elaborates the success factors of Yogyakarta City in determining SVTO which approaches the market price. The study used descriptive qualitative method with a case study design. The research data were obtained using in-depth interview and document review. The theoretical basis used was the pressure of isomorphism in institutional theory (DiMaggio \& Powell, 1983). The preliminary research was conducted at five Primary Tax Offices of Directorate General of Taxes (DGT) Regional Office in Daerah Istimewa Yogyakarta Province. The respondents of this study were employees of the Revenue and Regional Asset Management Office (BPKAD) Yogyakarta and Financial and Regional Assets Office (BKAD) Bantul. The results show that SVTO determination in Bantul is influenced by normative isomorphism pressure because Bantul follows the group norms of surrounding local governments. On the other hand, SVTO determination in Yogyakarta is influenced by coercive pressure because Yogyakarta tends to follow the laws and regulations. The essential lessons from Yogyakarta City are the readiness of regulations, use of reliable data, incentive provision, increase in the untaxable value of the sales value of taxable object, extensive socialization, and recruitment of appraisers. Bantul should refer to the Laws and Yogyakarta City, as the best practices in determining SVTO. This research can be a preliminary of further research in a broader area or on nationwide level.

\section{Introduction}

Since the issuance of Acquisition of Land and Building Taxes based on Law No. 28 of 2009 concerning Regional Taxes and Regional Retributions (RTRR Law), the local governments in Indonesia have been facing obstacles in determining Sales Value of Taxable Object (SVTO) as part of land and building taxes (LBT) management (Republik Indonesia, 2009). These obstacles vary significantly among regions. A study by Monding and Pusung (2017) shows that SVTO determination in Manado is still below the market price. Meanwhile, the determination of SVTO following market values seems to be a significant problem in Daerah Istimewa Yogyakarta (DIY). SVTO is regarded as far below the fair market price. The preliminary data collection regarding the comparisons of SVTOs and market prices in the regencies in DIY shows the following facts.

Table 1. Comparison of SVTO and Fair Market Value in DIY Province in 2019

\begin{tabular}{lccccc}
\hline \multicolumn{1}{c}{ City/Regency } & Object Number & Location & SVTO (IDR) & $\begin{array}{c}\text { Market Price } \\
\text { (IDR) }\end{array}$ & $\begin{array}{c}\text { Difference } \\
(\%)\end{array}$ \\
\hline \multirow{2}{*}{ Yogyakarta } & $34.71 .040 .002 .006-x x x x .0$ & Sorosutan & $1,274,000$ & $3,230,000$ & 254 \\
\multirow{2}{*}{ Sleman } & $34.71 .050 .001 .011-x x x .0$ & Prenggan & $2,176,000$ & $6,183,000$ & 284 \\
& $34.04 .050 .003 .005-x x x .0$ & Godean & $1,274,000$ & $13,011,225$ & 1.021 \\
\multirow{2}{*}{ Bantul } & $34.04 .060 .005 .011-x x x .0$ & Sinduadi & 614,000 & $5,009,000$ & 816 \\
\multirow{2}{*}{ Wates } & $34.02 .150 .002 .012-x x x .0$ & Niten & 200,000 & $2,264,000$ & 1.132 \\
\multirow{2}{*}{ Gunungkidul } & $34.02 .150 .004 .004-x x x .0$ & Soragan & 614,000 & $6,649,885$ & 1.083 \\
& $34.01 .070 .005 .070-x x x .0$ & Pengasih Kulon & 160,000 & 495,000 & 309 \\
\hline
\end{tabular}

Processed from Yogyakarta, Sleman, Bantul, Wates, and Wonosari tax offices

Table 1 shows that there are big gaps between SVTOs and market prices in Daerah Istimewa Yogyakarta Province. The gap between SVTO and market value in Yogyakarta City is the smallest compared to other regions. In contrast, SVTO in Bantul has the biggest disparity to the market prices. 
To strengthen the initial data, the researchers also conducted in-depth interviews with tax officials of Directorate General of Tax (DGT) DIY Province who stated that SVTO determined in all regencies did not match the market prices. The Account Representative of Wonosari Tax Office said:

"In Wonosari, in general, SVTO is not necessarily high. It depends on the region. In urban areas, it seems that it is still somewhat below the market price. However, for remote areas such as mountainous areas, most of them, [market prices if] compared to SVTO, are almost the same, but if compared to LVZ (Land Value Zone) of NLA (National Land Agency), LVZ of NLA is still too high. "

Meanwhile, in the interview, Head of Service Section at Bantul Tax Office provided the following information: "During this time, the price of SVTO on the annual notice of Land and Building Tax is below the market price. It is very far below the average market price. At least three times lower than SVTO..."

In early 2020, Government of Yogyakarta City made an adjustment to SVTO to catch up with the market price. For instance, SVTO of a tax object on Kusumanegara street increased up to 360 percent from IDR 3,745,000 to IDR 17,245,000 per meter. Also, in case of Urip Sumoharjo street, the data showed that there was an increase of about 34 percent. The adjustment was carried out based on Yogyakarta City Regional Regulation No. 2 of 2011 concerning Rural Urban Land and Building Taxes. The adjustment is believed to be a step to create a sustainable fair market prices as a mandate of regional regulations. Thus, Yogyakarta City is considered as a reference for harmonization between SVTO and market prices.

On the other hand, based on Bantul Regent Decree No. 1 (2020) on Determination of Sales Value of Taxable Object of 2020, Bantul did not increase SVTO level in 2020. The data from Information System of Taxable Object (SISMIOP) and Geographic Information System (GIS) showed that there was no difference between SVTO of 2019 and that of 2020.

Based on the phenomena that occur in DIY, this study investigates the success factors of Yogyakarta City, as the best practice, in establishing the proper SVTO. Then, this study elaborates the constraints in determining SVTO in relation to the fair market prices in Bantul Regency. Eventually, Bantul can take the lessons from the strategies and policies of Yogyakarta City. This research is expected to provide inputs for local governments in formulating rules and policies in determining appropriate SVTO at fair market prices. Moreover, this research differs from the previous studies because it focuses on SVTO valuation based on market values, which until now it is difficult to practice by the local governments. Finally, it will encourage future academic discussions on the application of fair value based on accounting principles put forward by IFRS and adopted by public sectors. The theories on public sector accounting and financial accounting will be elaborated to discuss the application of fair value in the determination of land and building tax by the local governments.

\section{Literature Review}

\section{Isomorphism}

Institutional Theory (in various forms) is not only related to the interactions of organizations with the political and economic environments, but also to the effects of institutional pressure on the organizations and the achievement of the expectations onto organizational behavior and character (Dillard et al., 2004). An institution is defined as a social structure that has reached a high level of resilience (Scott, 1987). Institutional pressure on private institutions will have the same level of influence on public institutions (Frumkin \& Galaskiewicz, 2004). DiMaggio and Powell (1983) describe coercive, mimetic, and normative mechanisms where institutional effects are spread through the organisational field, and emphasise structural isomorphism (equality) as an essential consequence of competitive and institutional processes. Scott (1987) argues that an organization is a social construction, which means that the organizational structure is a tool that is formed as a reaction to the characteristics and commitments of actors involved in the organization. The actors respond to the influence on and obstacles of the organization's external environment (Scott, 1987).

Isomorphic process has three different types. First, coercive/regulative isomorphism, that is subject to regulations, permits, and accreditation. This pressure arises when entities modify their institutional practices because of stakeholders' bargaining power, which is the basis of organisational dependence (DiMaggio \& Powell, 1983). Furthermore, the influential stakeholders may have the same expectations as other organisations and trigger a desire for conformity in the cross-organisational structures and practices, including the reporting practices.

The second type is normative isomorphism which refers to the associative environment where the organisation is established. It arises because of the pressure from 'group norms' to follow and apply certain institutional practices. Moreover, the pressure from certain groups will tend to force organisations to adopt similar practices, and disloyalty can result in penalties imposed by the group.

The last is mimetic isomorphism which looks at the performance of other organisations. It is believed that an organisation frequently duplicates the practices of others to get a competitive advantage and bring down uncertainty. Uncertainty is a firm pressure that promotes imitation (DiMaggio \& Powell, 1983). An organization 
imitates other organizations because it wants to gain proven benefits and competitive advantages. Firstly, the organization should try to understand and study the references of the successful organization. Then, the organization should assess whether it can adopt the specific best practices. In Isomorphism Theory, mimetic pressure occurs because one of the leading organizations influences others to change into conformity. Organisations in specific sectors adopt the practices similar to those adopted by the prominent organisations to improve the perception of external stakeholders on organisational legitimacy. However, without coercive pressure from the stakeholders, there would be no pressure to imitate others. Therefore, there is a relationship between mimetic isomorphism and coercion.

Institutional Theory explains how organisational actions are caused by external factors, social factors, public expectation factors, and environmental factors. In this study, coercive isomorphism explains how the local government must implement law and regulations to determine SVTO. Meanwhile, normative isomorphism is used to clarify Bantul's strategy in determining SVTO.

\section{Land and Building Tax}

According to Law Number 12 of 1994 concerning the Amendment to Law Number 12 of 1985 on Land and Building Tax (LBT Law), land is defined as a surface of the earth and the body of the ground beneath. Building is a structure that is planted in or established on land and/or body of waters (Republik Indonesia, 1994). Moreover, Rural and Urban Land and Building Tax (RU-LBT), according to RTRR Law, is a tax on land and/or buildings that are owned, controlled, and/or utilized by individual or entity, except the areas used for plantations, forestry, and mining. Based on the explanation of LBT Law, Land and Building Tax is a state tax in which most of the revenue is considered as regional income. It is used, among other things, to provide facilities that can be used by the central and regional governments. The amount of RU-LBT payable is calculated by multiplying the tariff with SVTO after deducted by the Un-taxable Value of the Sales Value of Taxable Object (UVSVTO). The formula is as followed.

Rate $\times($ SVTO - UVSVTO $)=$ Tax payable

\section{SVTO}

According to Article 6 Paragraph (1) of LBT Law, the basis to determine SVTO of Land and Building Tax is the average price of a reasonable transaction of sales and purchase. If there is no reasonable sales and purchase transaction, SVTO is determined through a comparison of the prices of other similar objects or new acquisition value or replacement of SVTO.

Table 2. The utilisations of SVTO in Indonesia

\begin{tabular}{|c|c|c|}
\hline No & Utilisation of SVTO & Primary Rule \\
\hline 1 & $\begin{array}{l}\text { The basis of Imposition of Rural and Urban } \\
\text { Land and Building Tax (RU-LBT) }\end{array}$ & $\begin{array}{l}\text { Law Number } 28 \text { of } 2009 \text { concerning Regional Taxes and Regional } \\
\text { Retributions (RTRR Law) }\end{array}$ \\
\hline 2 & $\begin{array}{l}\text { The basis of Imposition of Mining, } \\
\text { Plantation and Forestry Land and Building } \\
\text { Tax (MPF-LBT-P3) }\end{array}$ & $\begin{array}{l}\text { Law Number } 12 \text { of } 1994 \text { concerning the Amendment to Law Number } \\
12 \text { of } 1985 \text { concerning Land and Building Tax (LBT Law) }\end{array}$ \\
\hline 3 & $\begin{array}{l}\text { The basis of Imposition Acquisition Duty of } \\
\text { Right on Land and Building (ADRLB) }\end{array}$ & $\begin{array}{l}\text { Law Number } 20 \text { (2000) concerning the Amendment to Law Number } \\
21 \text { of } 1997 \text { concerning Acquisition Duty of Right on Land and } \\
\text { Building (ADRLB Law) }\end{array}$ \\
\hline 4 & $\begin{array}{l}\text { Basic indication for transaction fairness in } \\
\text { income-tax article } 4(2)\end{array}$ & $\begin{array}{l}\text { Directorate General of Tax Regulation Number PER-18 / PJ / } 2017 \\
\text { concerning Procedures for Research on the Evidence of the Fulfillment } \\
\text { of Obligations in Income Tax Payment on Income from Transfer of } \\
\text { Rights on Land and/or Buildings, and Binding Agreement of Sales and } \\
\text { Purchase of Land and/or Buildings and its Amendments }\end{array}$ \\
\hline 5 & The basis for a loan guaranteed by mortgage & $\begin{array}{l}\text { Financial Services Authority Regulation Number } 71 \text { /POJK.05/2016 } \\
\text { concerning Financial Health of Insurance Companies and Reinsurance } \\
\text { Companies }\end{array}$ \\
\hline 6 & $\begin{array}{l}\text { The basis for state property appraisal by } \\
\text { Local Government }\end{array}$ & $\begin{array}{l}\text { Bantul Regent Regulation Number } 56 \text { (2011) concerning Guidelines } \\
\text { for Valuation of Regional Property }\end{array}$ \\
\hline
\end{tabular}

Processed from various sources of laws and regulations.

SVTO is the average price of a property tax object that is appraised by an official assessment. The appraisal can be carried out by the government valuers, either from central or local government. Subsequently, this value is used as the basis for the imposition of property taxes. However, in Indonesia, SVTO is also used for the following utilisations. 
Table 2 shows that SVTO is very important not only in the public sector but also in the private sector. Generally, in the implementation of property taxes in Indonesia, land valuation uses market price comparison approach, while building valuation uses cost approach. Income approach is used as the comparison to the results of the two previous methods. The land is grouped in the Land Value Zone (LVZ), which is similar to Mean Indication Value (MIV). MIV is then used to calculate the land value for each property with the computer (Computer Assisted Valuation/CAV). The Building Component Cost List (BCCL) application is used to calculate the building value. Then, the value of the buildings for each property is calculated using CAV. For computer calibration and easy explanation for the taxpayers and other stakeholders, land values are grouped in 100 land classes, and building values are arranged in 40 building classes (Kementerian Keuangan, 1998)

\section{Appraisal}

In the developing and developed countries, local authorities commonly experience difficulties in appraising property taxes (Cesare, 1998) which happen for many reasons. The possible problems of taxation are generally related to lack of penetration to market information, omission of essential attributes in estimating the tax base, unreliable samples for estimation basis, deficiencies of frequent revaluations, and inaccuracies in real estate cadaster.

In various literatures, valuation is a term that is used interchangeably with appraisal. An appraisal is an act or process of developing an opinion of value (Appraisal Institute, 2001), which is the activity or process of forming an opinion on values. In general, there are three approaches used in the process of valuing a property, namely market price comparison, cost approach, and income approach (income capitalization approach) (Appraisal Institute, 2001). According to Rural-Urban Land and Building Tax General Guidelines by Ministry of Finance, valuation is an activity to determine the economic value of a property at a specific time or SVTO, which will be used as the basis for taxation (Kementerian Keuangan, 2014). It uses several approaches, such as market data approach, cost approach, and income capitalization approach in the form of written opinions.

\section{Fair Value}

Fair value is a reflection of the current market value of an asset (Rankin et al., 2012). AASB 13/ IFRS 13 defines fair value as the price that would be received from selling an asset or would be paid to transfer a liability in an orderly transaction between market participants on the measurement date. Furthermore, the standard-setter allows several assessment techniques based on the conditions and limitations. The first is market approach. This approach uses prices or relevant information obtained from transactions in the market. In addition, under certain circumstances, the cost approach could be an indicator of the current market value. The cost approach describes the amount needed at the moment to replace the service capacity of an asset. The last is income approach which is the estimation of the market value of an asset based on the present value of future cash inflows or income. It is also possible to calculate the present value of expenses in the future as a deduction.

It can be interpreted that fair value is more relevant to be used than other approaches since fair value reflects the current market prices. As a result, the amount emerges is the value that will be received if selling the assets in an active and open market. Overall, the valuation concept in RTRR Law and General Guidelines by Ministry of Finance aligns with the fair value in AASB 13/IFRS 13.

\section{Previous Research}

Several researchers had conducted studies on SVTO issue although they did not specifically investigate the success factors and constraints in determining SVTO close to the market price. The studies on potential revenues from increasing SVTO were conducted in Medan (Siahaan et al., 2019), Semarang (Ambarita et al., 2016), and Malang (Yunarti et al., 2016). Yunarti et al. (2016) found that the SVTO increase of 54\% was needed to reflect the real price in Malang Regency. Meanwhile, an analysis on the accuracy of SVTO level at a district in Manado was conducted by Monding and Pusung (2016) which revealed that the SVTO determination was still below the market price in that area. SVTO accuracy is closely related to regional revenue from land and building tax. However, the studies carried out still ignore the constraints underlying the determination of SVTO. Also, there has not yet a research on a region which succeeds in determining SVTO close to market prices. This study is the first one to elaborate the success factors in determining SVTO. The success factors in determining SVTO are valuable to solve the constraints faced by the other regions.

\section{Research Method}

This study applies a descriptive qualitative approach. Creswell states that qualitative research is a tool to explore and understand the views of individuals or groups related to social or human problems (Cresswell, 2014). Additionally, Hennink et al. (2011) describes qualitative research as an approach that allows researchers to appraise people's experiences in detail by applying data collection methods such as in-depth interviews, focus group 
discussions, observation, content analysis, visual methods, and life history. Qualitative research is an exploratory and in-depth research. It helps researchers in conducting research when essential variables cannot be determined and known beforehand.

This study not only provides factual reports but also generates an atmosphere of belief and thoughts that develop in the cases subject to a study that cannot be captured by rigorous quantitative research. Case study is a way to gain an understanding of a program, event, activity, process, or more individuals. Cases are linked by time and action, and data are collected through various procedures in a sustained period (Stake, 1995). A case study allows investigators to focus on a "case" and retain a holistic and real-world perspective such as organizational and managerial processes, as well as group behavior (Yin, 2014). It is expected that this case study will reveal specific, unique, and very detailed things that cannot be explained by other studies. Case studies uncover the meaning underlying phenomena in their natural conditions.

This qualitative research employed a multi-case study approach. The use of a multi-case study approach in this research was based on the need to obtain more in-depth information related to the phenomenon under study. It is in line with the view expressed by Yin (2014), that research results from multi-case studies are often seen as more exciting and in-depth.

The data analysis of this study was carried out in two stages. It began with an analysis on the individual case data which was followed by cross-case analysis. The analysis on the individual case data was carried out to determine the problems/causal factors in each region. In contrast, the cross-case data analysis was intended to determine the similarities and/or differences in the characteristics of each individual case.

\section{Research Samples}

The object of this research is Financial and Regional Asset Office (BKAD) of Bantul Regency and Revenue and Regional Asset Management Office (BPKAD) Yogyakarta City. The study focused on the departments that managed RU-LBT. The respondents were the employees who were actively involved in the process of data collection, appraisal, and management of land and building tax. The data used in this study were primary data obtained from the interviews with the participants. The sampling method used purposive sampling, which focuses on participants who have specific characteristics or in-depth experience of a topic that can provide a deep understanding on the research issues (Hennink et al. 2011).

Table 3. List of Participants Code

\begin{tabular}{|c|c|c|c|c|}
\hline Code & Office & Role of Duty & $\begin{array}{l}\text { Number } \\
\text { of } \\
\text { interviews }\end{array}$ & $\begin{array}{c}\text { Duration of } \\
\text { interview } \\
\text { (minutes: } \\
\text { seconds) }\end{array}$ \\
\hline MR1 & BPKAD Yogyakarta & $\begin{array}{l}\text { Head of Services, Registration, and Determination of } \\
\text { Regional Taxes Department }\end{array}$ & 1 & $25: 00$ \\
\hline MR2 & BPKAD Yogyakarta & Head of Sub-division of Determination of Regional Taxes & 1 & 29:48 \\
\hline MR3 & BPKAD Yogyakarta & Regional Tax / Retribution Analyst & 1 & $26: 34$ \\
\hline MR4 & BPKAD Yogyakarta & Regional Tax / Retribution Analyst & 1 & 23:46 \\
\hline MR5 & BPKAD Yogyakarta & Map and Information System Staff & 1 & $32: 22$ \\
\hline MR6 & BKAD Bantul & $\begin{array}{l}\text { Head of Services and Determination of Regional Taxes } \\
\text { Department }\end{array}$ & 1 & 23:14 \\
\hline MR7 & BKAD Bantul & $\begin{array}{l}\text { Head of Sub-division of Data Collection, Appraisal, and } \\
\text { Determination }\end{array}$ & 1 & $21: 27$ \\
\hline MR8 & BKAD Bantul & Head of Sub-division of Services & 1 & $25: 08$ \\
\hline MR9 & BKAD Bantul & $\begin{array}{l}\text { Head of Sub-division of Data Processing and Information } \\
\text { of Regional Revenue }\end{array}$ & 1 & $35: 39$ \\
\hline MR10 & BKAD Bantul & Regional Tax / Retribution Analyst & 1 & $20: 49$ \\
\hline
\end{tabular}

\section{Data Collection}

In conducting interviews, the researchers prepared an interview guidelines based on the interview development guidelines by Hennink et al. (2011). The interview guidelines depend on the types of research questions as well as the aims and objectives of the study. The researchers conducted individual face to face interviews with the participants. The questions designed were in the form of semi-structured and open-ended questions to bring up the views and opinions of the participants. The questions raised were related to the SVTO and property market prices in the region and the constraints in determining the SVTO. Besides, another important focus was the questions regarding the dimensions of isomorphism in the form of coercive, normative, and mimetic pressures. This research also used secondary data obtained directly from the respondents and the government official websites. The 
documentation conducted in this study was investigating laws, regulations, standard operating procedures, and archives related to the appraisal of tax objects.

\section{Data Analysis}

Qualitative research data analysis consists of several stages (Cresswell 2014). First, the researcher compiled and prepared the data for review. The data analysis was carried out during and after data collection. The steps involved transcribing the interview results, scanning materials, reducing data, and organising data into categories. Second, the researcher focused on reading the entire data. The researcher built a general sense of all information obtained and reflected the meaning of the data. Third, the coding process was done to describe the information. Rossman and Rallis state that coding is the process of organizing data by collecting pieces and writing categories within boundaries (Cresswell 2014). In the coding process, the researcher made a small number of themes or categories which would be the main results of the research. Last, the researcher made the interpretations as an effort to understand the results of the study.

\section{Test of Validity and Reliability}

To test the validity and reliability of the data, the researchers used source triangulation. The idea behind the triangulation was that one could be more confident in the results if the use of different methods or sources led to the same results (Sekaran \& Bougie, 2016). The researchers used source triangulation to examine the data from different participants collected using the same method. Source triangulation checked the validity of the data by comparing the interview results of one participant with those of other participants. Besides, the member check activity in this research was carried out by conveying the conclusions of the interview results to the participants. When the interviewees agreed with the results, the interviewees were asked to sign the member check sheet as a sign of agreement.

\section{Results and Discussion}

In the general data analysis, the researchers provide an overview on the SVTO conditions and the participants' perceptions about the importance of SVTO so that the general practice being experienced at that time can be known.

\section{Current SVTO Level}

The conditions between Yogyakarta City and Bantul Regency are very contradictory. All respondents from BPKAD Yogyakarta stated that their SVTO level was close to the fair market price. On the other hand, in Bantul, the SVTO is still far from the market prices.

Yogyakarta City, as a reference, has successfully set the SVTO close to the fair market price. It is also reflected in the statements of all respondents working as BPKAD officers in Yogyakarta. MR1 respondent mentioned:

"Inshallah, this year, we adjusted to the market prices, and we used ADRLB transactional data reported and researched by our coworkers, we recorded and based on the Acquisition Duty of Right on Land and Building (ADRLB) transactions until 2018. Then we also used LVZ data from NLA 2017. Inshallah, if there was a gap, it was just a little. However, yes, consequently, SVTO surged, and some reached 400 percent." (MR2.2)

In contrast, Bantul Regency is still struggling to implement the SVTO by the market price. All participants at BKAD office admitted that their level of SVTO was under the market price level. Respondent MR7 stated:

"Now, on average, the selling value of tax objects in the Bantul Regency is not yet in line with the market value. In consideration that if we can get in sync with the market value, there will be a very significant increase. However, averagely, our market value ranges from 40 to 60 percent of the market value." (MR7.2)

\section{Perceptions on SVTO}

Nine out of ten participants from BPKAD Yogyakarta dan BKAD Bantul gave explicit statements about the importance of SVTO following the market prices. Personally, local tax officials had the same perception. MR3 respondent gave reasons for the significance of fair market prices as a reference.

"Because many things ... some parties are interested in using SVTO, we think it is also important for us to bring SVTO to market price level." (MR3.3) 
In the interviews, four out of ten respondents from BPKAD Yogyakarta and BKAD Bantul claimed that the community did not agree with the SVTO concept following the market prices. Then, four respondents stated that SVTO, according to market prices, resulted in pros and cons in the community. The interview excerpts below reflect the ideas of the participants.

"The public as a matter of fact, if we want to socialise, they understand that..., understand that what we have set is still far, it can be accepted in gradual step, not instantly". (MR6.2)

"If the SVTO is close to the market prices, I think if the tariff is still constant, most likely not yet. I am personally or my own opinion." (MR10.7)

"Yes, well yes, Sir, it is just like buah simalakama (between the devil and the deep sea). In my mind, and also for the public. When they need it, for example, like compensation from the community, eh, the government for the replacement of their land, they will surely demand a high SVTO by the market prices. However, when it applies to the tax determination process that ultimately becomes their obligation, they will undoubtedly want it to be below the market price. It is a dilemma." (MR4.7)

Overall, most respondents claimed that the public did not agree with the concept of market prices applied in SVTO. It is the opposite of the perceptions of tax officials who agreed with the application of market prices on SVTO adjustment.

\section{Best Practice and References}

Five respondents from BPKAD Yogyakarta and BKAD Bantul stated that there was no best practice being imitated. Three respondents stated the opposite, while the rest did not give any comments on this topic. However, Bantul Regency did not imitate any best practice from other areas, although there had been several comparative studies. It is consistent with the description of the MR8 respondent as follows.

"Comparative studies are often carried out, and each region has its own benefit. There is a benefit in service, in its passive service. In contrast, there is an area that is superior in active service. So, there are many employees, they often do data collection. Where there is less workforce, 73ptimizing with the existing system, then, just waiting for submissions. Each region has its character as well." (MR8.11)

All respondents from BKAD Bantul stated that it was challenging to imitate Yogyakarta City as the best practice. The following is the statement of respondent MR7 elaborating on the reasons why Bantul was not able to imitate the practice in Yogyakarta City.

"In our opinion, it is difficult for the policy like that of the city to be implemented in Bantul, Sir. Because of the public culture, the city is already an urban area. The area is not too broad. In Bantul, the area is much more extensive, so the price of land is also very varied. There are agglomerating locations. Some are still mountainous. So if trying to duplicate the city, raising it like their approach, in Bantul, it is not possible. Besides, including human resources, the community's level of education between Bantul and the City is also different." (MR7.15)

\section{Analysis on Individual Case}

This study has revealed the several success factors of Yogyakarta City based on the result of interviews with the respondents and document review. According to five participants at BPKAD Yogyakarta, the critical factors for the success in determining SVTO to be set according to the market prices can be grouped into six criteria, namely 1) regulation, 2) data validity, 3) incentive allocation, 4) SVTO uplift, and 5) human resources.

\section{Regulations}

Government of Yogyakarta City changed several rules and regional regulations in 2019. Yogyakarta City implements Yogyakarta City Regional Regulation Number 9 of 2019 concerning Amendment to the Yogyakarta City Regional Regulation Number 2 of 2011 on Rural-Urban Land and Building Taxes as a legal basis and guidance in the collection of RU-LBT (Kota Yogyakarta, 2019c). The instruction for the implementation of the regulation is stated in the Regulation of Yogyakarta Mayor Number 96 of 2019 concerning the Second Amendment to the Yogyakarta Mayor Number 83 of 2011 (Kota Yogyakarta, 2019d). All revisions to the existing rules are carried out in the anticipation of all possible effects of the determination of SVTO by market prices. The Government of Yogyakarta City has carefully been prepared for the impacts that will emerge so that there are minimum harmful effects. Briefly, Yogyakarta City Regional Regulation Number 9 (Kota Yogyakarta, 2019c) focuses on changes in the Un-taxable Value of the Sales Value of Taxable Object (UVSVTO). Meanwhile, Yogyakarta Mayor Regulation Number 96 of 2019 is intended to manage the tax deduction. Both complement the Decree of Yogyakarta Mayor Number 512 of 2019 concerning Determination of Selling Value of Land and Building Tax Objects as the Basis for Imposing Rural-Urban Land and 
Building Tax in Yogyakarta City in 2020 which serves as the foundation to determine RU-LBT in 2020 (Kota Yogyakarta, 2019a). As a result, these three rules are mutually related and supportive to the implementation of the SVTO determination that approaches the market prices in Yogyakarta City.

\section{Data Validity}

In determining SVTO, the mechanism for applying the market data comparison approach involved the use of comparative property transaction data. This approach was done by comparing properties that were valued with other similar properties that had been sold or offered for sale. One of the crucial activities that must be carried out in the process of using the market data comparison approach is collecting the comparative data and determining the relevant comparative data. The apparatus of BPKAD Yogyakarta believed its SVTO quality was close to market prices because it used relevant and valid data. The respondent, MR1, claimed that the data reflected the comparison of real transactions and LVZ by NLA. Thus, the data collected internally from the transaction recapitulation on ADRLB were confirmed by the value of a third party.

"The City's Government of Yogyakarta brought SVTO to market prices with the formulation: ADRLB data, real transactions, and the existence of Indonesia's Corruption Eradication Commission (Komisi Pemberantasan Korupsi/KPK) letter to utilise LVZ by the regional office of the National Land Agency (NLA)." (MR1.1)

\section{Incentive Allocation}

\section{Yogyakarta City}

Yogyakarta City provides a deduction factor to the tax payable named stimulus. As mentioned earlier, Yogyakarta City Regional Regulation Number 9 (Kota Yogyakarta, 2019c) focuses on reducing taxes. Furthermore, article 15 states that the Mayor can provide a reduction of RU-LBT payable without any request from the taxpayer. Eventually, this article becomes the legal basis to provide stimulus to taxpayers who are affected by the increase in property tax.

The amount of stimulus provided is regulated in the Decree of Yogyakarta Mayor Number 515 (2019b). In its consideration, the determination of the amount of property tax stimulus is intended to avoid public turmoil. It is supported by the opinion of respondent MR4 saying that the incentive is a mitigation effort so that the tax payable is not too high.

"... To mitigate the land and building tax levied in order not to increase very highly, since without social affirmation, the average increase is almost $400 \%$. However, with a tiered social stimulus according to the tariff class, the average increase is around 60 percent. " (MR4.6)

\section{UVSVTO Uplift}

Recalling formula of property tax; tax payable is the result of the rate multiplied by the Taxable Sales Value (TSV), SVTO minus UVSVTO. Thus, an increase in SVTO accompanied by the rise in UVSVTO will control the increase in TSV. In 2019, the issuance of Yogyakarta City Regional Regulation Number 9 of 2019 was an attempt by the government to increase UVSVTO. In the current rule, the value of UVSVTO, which was only IDR 12,000,000, was increased to IDR 20,000,000. In consideration, the House of Representatives and the Mayor stated that the existing UVSVTO did not match the current situation. Moreover, this fact was also conveyed by MR4 respondent as follows.

"... the city's government is also doing this, what is the name, social affirmation. The first is the social affirmation that prior value is 12 million, but this year 20 million starts to be applied..." (MR4.6)

\section{Human Resources}

In conducting land and building valuation, an expert appraiser with adequate education and training is required. Based on the interviews, the participants at BPKAD Yogyakarta stated that appraiser officials were essential. The appraisers are primary officers in the valuation of land and buildings as the basis to establish the SVTO. The city government takes the strategic steps to sustainably maintain a proper SVTO. In 2019, the recruitment of property appraisers was carried out. This workforce is to support the business processes in taxation sector at BPKAD. This information was mentioned by the MR1 respondent as follows.

"... In 2019, the additional five new candidates were recruited for civil servants specifically serving as property tax appraisers." (MR1.6)

\section{Bantul Regency}

Based on the results of the document review and interviews conducted with seven participants in Bantul Regency, the factors that cause the constraints in fixing SVTO according to the market prices can be identified. These factors 
can be grouped into five criteria, namely 1) regulation, 2) data validity, 3) map and land value zone quality, 4) influence of surrounding environment, and 5) human resources.

\section{Regulation}

Based on the results of the interviews with Bantul BKAD participants, Bantul has never raised SVTO highly, so the existing regulations are still adequate. The increase in SVTO level is only around one or two classes. Based on these reasons, upgrading regulation is not an urgent matter. Bantul only has Bantul Regency Regional Regulation Number 18 of 2011 to set SVTO approaching the market prices. There is no regent regulation concerning the procedures to implement the regional regulation. Besides, Bantul also has no regulation regarding the provision of stimulus as an incentive. A stimulus is needed to remit the increase in taxes due to SVTO adjustment.

\section{Data validity}

Three out of five respondents in Bantul stated that low quality of data was another obstacle in determining SVTO. Bantul does not have valid and comprehensive market price transaction data in each area. Therefore, a reliable data collection is an essential step to keep up with the market prices.

"The first one is external, or if all the data are sufficient, then it can be generated. If it is fulfilled, SVTO can be adjusted to the market value..." (MR8.16).

\section{Map and Land Value Zone Quality}

All respondents from BKAD Bantul stated that there was a need to raise SVTO step by step. However, it was not clear how long it would take to reach a fair market price. The officer from the mapping section clearly stated that the quality of maps in the information system was not adequate. An invalid map will lead to an error in the formation of land price zone. As a result, the SVTO for an object can be mistaken. The improvement in mapping and land value zone is an urgent matter. A respondent from Bantul expressed the following view.

"Because it still needs a process. Frankly, the first concern is to fix LVZ. The map must be standardised at first. We are heading to that direction since it was handed over to the regional government. We have only just adjusted the maps according to the National Land Agency, only a few villages..." (MR10.19)

\section{Influence of Surrounding Environment}

Normative pressure occurs because of the stress from the group in conducting certain institutional practices. The community of local governments can be interpreted as a reference group. Almost all participants, eight out of ten, stated that in general many regions do not set SVTO at fair market prices. The current conditions are common and experienced by most of the regions.

"When we see it, it must be like that, Sir. Except, perhaps Yogyakarta City, Sir. Recently, it was adjusted. For example, We are with Sleman. Our border with Sleman, we were even higher than Sleman. Indeed, Sleman's policy is not to increase SVTO. It seems like since the delegation to them. They have never adjusted SVTO. Yes, it can be said that it is almost the same. Our neighbours have not yet adjusted SVTO according to market value. Except for the city which recently already started to get closer [to the market price]." (MR7.17)

Respondent MR7 mentioned that Yogyakarta City was the region that had adjusted its SVTO to the market prices. MR6, on the other hand, mentioned that the SVTO of other regions were still below the fair market price. Overall, the influence of the surrounding environment causes local governments to feel comfortable when setting SVTO below market prices. Normative pressure is pragmatically stronger than regulative pressure.

\section{Human Resources}

Inadequate expertise in property valuations coupled with limited technical appraisal training are indicative of limitation in HR competency. The limitation in HR competence has an impact on the suboptimal adjustment of SVTO to market prices. Until now, BKAD Bantul does not have functional appraisal officials. The number of employees in Bantul BKAD is only 25 people. Hence, it must be balanced by improving the quality of the human resources. From the interviews, the researchers obtained the following statement.

"If the number is not yet added, if there are quality or ability problems, everyone, if they learn even a little, they will be able to. However, when it comes to number, it is a bit overwhelmed. For us, for the division of territories, for the settlement of the LBT, there is only one person that is responsible for 3 Districts. It is not effective for us to control three sub-districts of such breadth." (MR8.9) and; 
"In structure, organisational structure, talking about organisational structure, I believe the determination of SVTO is already fine with the organisation. But, the manpower, I believe, we have a lack of credible manpower to make the SVTO match to the market price." (MR9.11)

\section{Cross Case Analysis}

Cross-case data analysis was conducted to elaborate on the similarities and differences of the success factors of Yogyakarta City and the constraint factors of Bantul so that the conclusions between cases can be drawn. The comparison is explained as follows.

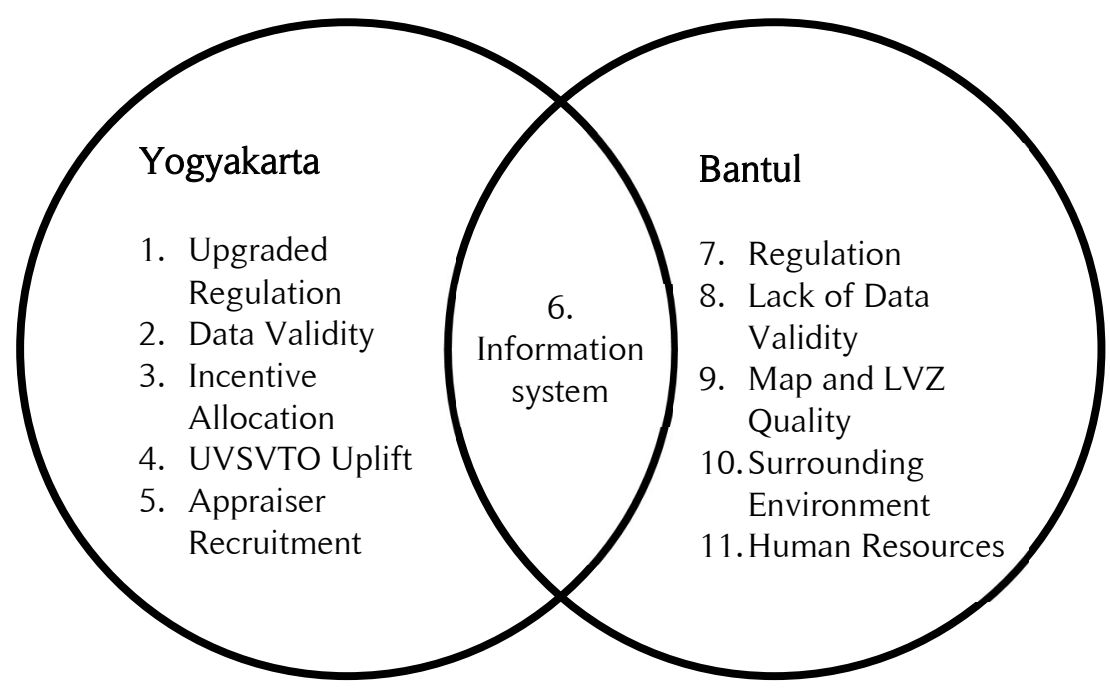

Figure 1. Cross-Case Analysis- Overall Factors in Yogyakarta City and Bantul

The characteristic factors that only exist in Yogyakarta are 1, 2, 3, 4, and 5. These are the success factors for Yogyakarta to adjust SVTO to market values. Meanwhile, factors that only exist in Bantul are 7, 8 9, 10, and 11. These become obstacles in adjusting SVTO according to market values. Meanwhile, information system factor is a common factor that exists in both parties to support the determination of SVTO following market prices. Through cross-case analysis, it can be mapped that factors $7,89,10$, and 11 are factors that need to be improved. Improvements made by Bantul can refer to factors 1, 2, 3, 4, and 5 in Yogyakarta City.

\section{Regulations}

Related to regulations, both Yogyakarta City and Bantul Regency have similarities in terms of the issuance of regional regulations on rural urban land and building tax since 2011. The regulation is a form of RTRR Law implementation.

However, the city of Yogyakarta has amended the regional regulations by raising the UNSVTO and issuing the regulations on granting direct tax reductions (stimulus). On the other hand, Bantul still does not have the rules regarding tax incentives. There has also been no change to local regulations issued since 2011 to respond to changes and developments.

\section{Data Validity}

The validity of data is a success factor of the City of Yogyakarta in bringing SVTO closer to market prices. BPKAD of Yogyakarta City uses real transactions from ADRLB data verified by tax analysts. Then, KPK assisted by recommending the use of Land Value Zone data from National Land Agency.

In contrast, the validity of data becomes an obstacle for Bantul Regency to establish the SVTO in line with market prices. The information obtained revealed that large and mountainous areas made it challenging to compare property market prices between areas. The Head of Determination and Assessment Division of BKAD Bantul stated that land values based on land value zones by National Land Agency are not in accordance with the market prices and are considered too high.

\section{Incentive Allocation}

One critical factor for the City of Yogyakarta to increase the SVTO is the existence of tax incentives. Government of Yogyakarta City provides incentives in the form of stimulus. Based on the Mayor's Decree, the stimulus granted is up to $75 \%$ of the tax payable. According to participants of BPKAD Yogyakarta, the incentive is given as an effort 
to mitigate the emergence of public protests. On the other hand, Bantul Regency does not have the regulations to provide direct tax reduction (stimulus). Every tax reduction must go through a direct request by the taxpayer.

\section{UVSVTO Uplift}

Related to UVSVTO, Yogyakarta City and Bantul Regency have different levels. In 2019, UVSVTO of Yogyakarta City was IDR 12,000,000, while that of Bantul Regency was IDR 10,000,000. In 2020, the Bantul Regency increased the amount of UVSVTO to IDR 20,000,000 which means an increase in the value of taxable objects that are not taxed. According to the participants, the rise in UVSVTO is a joint effort by the city government and the house of representative to reduce the amount of tax payable.

Meanwhile, Bantul Regency since 2011 has never changed the SVTO level. Based on the participants' statements, the current regulatory conditions become one of the obstacles to raise the SVTO according to market prices.

\section{Map and Land Value Zone Quality}

In terms of map and land value zones quality, the City of Yogyakarta and Bantul Regency have similarities, in which both use Tax Object Information System (SISMIOP), Geographic Information System (GIS), and Property Market Value Data Bank (PMVDB) in managing land and building tax. The information system is inherited from Directorate General of Taxes since 2011 when there was a transfer of land and building tax management.

The existing system depends on the input made by the officers. Based on the interviews with BPKAD Yogyakarta officials, the increase in SVTO is the result of input data from the real transactions from ADRLB file. However, BKAD Bantul officers have so far only upgraded the land classes; the most recent was in 2018, of one or two levels. Hence, in general, there are no problems with the information system. The input data improvement is needed in Bantul Regency. Furthermore, the tax analysis officer of BKAD Bantul explained that the improvement of map quality and land value zones should have been carried out with the direct data collection program.

\section{Influence of Surrounding Environment}

Yogyakarta City and Bantul Regency are relatively in the same area, namely Special Province of Yogyakarta. Both BPKAD Yogyakarta and BKAD Bantul are the members of Regional Revenue Office forum in DIY Province. The forum is held once every three months. Based on the interviews with the participants from Bantul BKAD, the condition of the SVTO in DIY Province is still below the market price except for Yogyakarta City. Also, the level of the SVTO in Bantul was not much different from that of other regions. Meanwhile, based on the statement of the participants from BPKAD Yogyakarta, the Government of Yogyakarta City saw that each area had its conditions and characteristics. BPKAD Yogyakarta only carries out the mandate of the regulations and directives from Corruption Eradication Commission to adjust SVTO with the market prices.

\section{Human Resources}

In terms of human resources, BPKAD Yogyakarta and BKAD Bantul have similarities, especially in terms of limited competent human resources. Based on the results of the interviews with the participants, the expertise of the personnel in the valuation and SVTO determination of property valuation management is still considered inadequate. Also, the training aimed at improving human resource competence is still minimal. These government agencies have not had land and building tax appraisers.

However, in 2019, BPKAD Yogyakarta recruited prospective civil servants as property appraisers. They were prepared to maintain the quality of SVTO in the city of Yogyakarta to follow market prices. On the other hand, BKAD Bantul has not yet recruited property appraisers.

\section{Conclusion}

This study reveals that there is a correlation between the mechanism of isomorphism in the success of determining SVTO approaching the current market prices. Local governments with strong regulatory pressures will tend to set SVTO close to market prices. On the other hand, local governments with strong normative pressure will tend to set SVTO below market prices because other regional governments generally carry out the same policies. This study found that the local governments' responses to the coercive pressure tended to set SVTO as a reflection of fair market prices.

The results of this study suggest that Bantul implement the strategies implemented by Yogyakarta City. The following are the efforts that can be conducted by Bantul Regency: upgrading regulation, improving data validity, allocating tax incentives such as stimulus, generating UVSVTO uplift, and recruiting appraisers as expert officials in property valuation. 
Coercive Mechanism in Yogyakarta City is practiced by implementing Yogyakarta City Regional Regulation Number 9 of 2019 concerning Amendment to the Yogyakarta City Regional Regulation Number 2 of 2011 on Rural-Urban Land and Building Taxes. Besides, to mitigate the increase in tax increases, Yogyakarta City issued Decree of Yogyakarta Mayor Number 515 of 2019 concerning Determination of Amount of Grant for RuralUrban Land and Building Tax Stimulus in 2020. Meanwhile, in other local governments, the normative mechanism is stronger because of the equality of policies between local governments in the DIY region. Based on the experience of Yogyakarta, coercive pressure can be a reference for other regional governments supported by a mimetic mechanism by making Yogyakarta as best practice.

This research was conducted at the time of the COVID-19 pandemic, so, it was difficult for the researchers to conduct observations in this study. This becomes the limitation of this study. Besides, most the interviews and data collected were in Bahasa Indonesia, although the study is presented in English.

Based on the conclusion above, the researchers give some recommendations at practical level as follows. First, Bantul, and other regions are expected to make Yogyakarta City as the best practice, a benchmark. Second, local governments can consider the suggestions of some respondents, that an increase in SVTO can be an offset not only by providing stimulus and increasing UVSVTO, but also a decrease in tax rates. Last, Yogyakarta City may provide a blueprint of strategies and steps to overcome the problems of public resistance in the determination of SVTO. Therefore, it can be a reference for other regions and increase mimetic pressure to other regional governments towards a reliable SVTO.

This study also provides recommendations at academic level. First, the research can encourage similar research for a broader and nationwide area. Next, the research on taxpayers' perceptions on SVTO concept according to market prices can be conducted in the future. Finally, this research might inspire a more comprehensive discussion about isomorphic pressure in the public sector. This discussion is to confirm the regulative pressures that occur because of stakeholders' bargaining power. It is because the community as stakeholders reject the increase in SVTO while the House of Representative accepts the idea.

\section{References}

Ambarita, S., Subiyanto, S., \& Yuwono, B. D. (2016). Analisis perubahan zona nilai tanah berdasarkan harga pasar untuk menentukan nilai jual objek pajak (NJOP) dan peningkatan pendapatan asli daerah (PAD) (studi kasus : Kec. Semarang Timur, kota Semarang). Jurnal Geodesi Undip, 5(2), 159-167.

Appraisal Institute. (2001). The Appraisal of Real Estate (Twelfth Ed). Appraisal Institute.

Cesare, C. M. De. (1998). An Empirical Analysis of a Property Tax System: A Case Study from Brazil. University of Salford.

Cresswell, J. W. (2014). Research Design: Qualitative, Quantitative, And Mixed Method Approaches. Fourth Edition. Thousand Oaks.

Dillard, J. F., Rigsby, J. T., \& Goodman, C. (2004). The making and remaking of organization context: Duality and the institutionalization process. Accounting, Auditing \& Accountability Journal, 17(4), 506-542. https://doi.org/10.1108/09513570410554542

DiMaggio, P. J., \& Powell, W. W. (1983). The iron cage Revisited: Institutional isomorphism and collective rationality in organizational fields. American Sociological Review, 48(2), 147-160. https://doi.org/10.2307/2095101

Frumkin, P., \& Galaskiewicz, J. (2004). Institutional isomorphism and public sector organizations. Journal of Public Administration Research and Theory, 14(3), 283-307. https://doi.org/10.1093/jopart/muh028

Hennink, M., Hutter, I., \& Bailey, A. (2011). Qualitative Research Methods. Sage Publications.

Kabupaten Bantul. (2011). Peraturan Bupati Bantul Nomor 56 Tahun 2011 tentang Pedoman Penilaian Barang Milik Daerah. Berita Daerah Kabupaten Bantul Nomor 56 Tahun 2011. Sekretariat Daerah Kabupaten Bantul.

Kabupaten Bantul. (2020). No Keputusan Bupati Bantul Nomor 1 Tahun 2020 tentang Penetapan Besarnya Nilai Jual Objek Pajak Sebagai Dasar Pengenaan Pajak Bumi dan Bangunan Perdesaan dan Perkotaan Di Wilayah Kecamatan Se Kabupaten Bantul Tahun Pajak 2020. Berita Daerah Kabupaten Bant. Sekretariat Daerah Kabupaten Bantul.

Kementerian Keuangan. (1998). Keputusan Menteri Keuangan Nomor 523/KMK.04/1998 tentang Penentuan Klasifikasi dan Besarnya Nilai Jual Objek Pajak Sebagai Dasar Pengenaan Pajak Bumi dan Bangunan. Sekretariat Kementerian Keuangan. 
Kementerian Keuangan. (2014). Pedoman Umum Pengelolaan Pajak Bumi dan Bangunan Perdesaan dan Perkotaan. Sekretariat Direktorat Jenderal Perimbangan Keuangan.

Kota Yogyakarta. (2019a). Keputusan Walikota Yogyakarta Nomor 512 Tahun 2019 tentang Penetapan Nilai Jual Objek Pajak Bumi dan Bangunan Sebagai Dasar Pengenaan Pajak Bumi dan Bangunan Perdesaan dan Perkotaan Kota Yogyakarta Tahun 2020. Sekretariat Daerah Kota Yogyakarta.

Kota Yogyakarta. (2019b). Keputusan Walikota Yogyakarta Nomor 515 Tahun 2019 tentang Penetapan Besaran Pemberian Stimulus Pajak Bumi dan Bangunan Perdesaan dan Perkotaan Tahun 2020. Sekretariat Daerah Kota Yogyakarta.

Kota Yogyakarta. (2019c). Peraturan Daerah Kota Yogyakarta Nomor 9 Tahun 2019 tentang Perubahan atas Peraturan Daerah Kota Yogyakarta Nomor 2 Tahun 2011 tentang Pajak Bumi dan Bangunan Perdesaan dan Perkotaan. Lembaran Daerah Kota Yogyakarta Tahun 2019 Nomor 9. Sekretariat Daerah Kota Yogyakarta.

Kota Yogyakarta. (2019d). Peraturan Walikota Yogyakarta Nomor 96 Tahun 2019 tentang Perubahan Kedua atas Peraturan Walikota Yogyakarta Nomor 83 Tahun 2011 tentang Petunjuk Pelaksanaan Peraturan Daerah Kota Yogyakarta Nomor 2 Tahun 2011 tentang Pajak Bumi dan Bangunan Perdesaan dan. Sekretariat Daerah Kota Yogyakarta.

Monding, R. O. H. ., \& Pusung, R. J. (2016). Analisis tingkat akurasi penetapan nilai jual objek pajak (NJOP) bumi dan bangunan di kecamatan Paal Dua kota Manado. Jurnal EMBA: Jurnal Riset Ekonomi, Manajemen, Bisnis Dan Akuntansi, 4(4), 993-1000.

Rankin, M., Ferlauto, K., McGowan, S. C., \& Stanton, P. A. (2012). Contemporary issues in accounting. Wiley.

Republik Indonesia. (1994). Undang-undang Nomor 12 Tahun 1994 tentang Perubahan atas Undang-undang Nomor 12 Tahun 1985 tentang Pajak Bumi dan Bangunan. Lembaran Negara RI tahun 1994 Nomor 62. Sekretariat Negara.

Republik Indonesia. (2000). Undang-undang Nomor 20 Tahun 2000 tentang Perubahan atas Undang-Undang Nomor 21 Tahun 1997 tentang Bea Perolehan Hak Atas Tanah dan Bangunan. Lembaran Negara RI tahun 2000 Nomor 130. Sekretariat Negara.

Republik Indonesia. (2009). Undang-undang Nomor 28 Tahun 2009 tentang Pajak Daerah dan Retribusi Daerah. Lembaran Negara RI tahun 2009 Nomor 130. Sekretariat Negara.

Scott, W. R. (1987). The Adolescence of Institutional Theory. Administrative Science Quarterly, 32(4), 493-511. https://doi.org/10.2307/2392880

Sekaran, U., \& Bougie, R. (2016). Research Method for Business Textbook: A Skill Building Approach. Wiley.

Siahaan, E., Fachruddin, K. A., \& Fachruddin, H. T. (2019). Optimization of updating land and building tax object in improving local own-source revenue for Medan development acceleration. ABDIMAS TALENTA: Jurnal Pengabdian Kepada Masyarakat, 3(2), 141-147. https://doi.org/10.32734/abdimastalenta.v3i2.4036

Stake, R. E. (1995). The Art of Case Study Research. Sage Publications.

Yin, R. K. (2014). Case study research: Design and methods (5th ed.). Sage Publications.

Yunarti, D. A., Wilopo, \& Mayowan, Y. (2016). Potensi pajak bumi dan bangunan sektor perdesaan dan perkotaan (PBB-P2)(studi kasus di kabupaten Malang ditinjau dari perbedaan harga pasar wajar dengan nilai jual objek pajak (NJOP) bumi yang berlaku). Jurnal Mahasiswa Perpajakan, 8(1), 1-10. 


\section{Appendix}

1. Interview Guide Questions

2. Interview Transcripts

3. Recapitulation of General Sense of information

4. Recapitulation of Themes and Sub-themes

5. Tabulation of Themes and Sub-themes of Participants

Appendix 1. Interview Guide Questions

\begin{tabular}{|c|c|c|c|c|}
\hline Code & & Transcript & Dimension & Objectives \\
\hline Q & 1 & $\begin{array}{l}\text { Apakah NJOP di Kota Yogyakarta sudah sesuai dengan } \\
\text { harga pasar? }\end{array}$ & Coercive Pressure & $\begin{array}{l}\text { To find out the compatibility of SVTO } \\
\text { with regulations. }\end{array}$ \\
\hline Q & 2 & $\begin{array}{l}\text { Apakah Nilai NJOP yang sesuai harga pasar wajar } \\
\text { merupakan hal yang penting? }\end{array}$ & Coercive Pressure & $\begin{array}{l}\text { To find out the perception of coercive } \\
\text { pressure for participants. }\end{array}$ \\
\hline Q & 3 & $\begin{array}{l}\text { Apakah dalam Peraturan (misal Peraturan Walikota) } \\
\text { telah diamanatkan agar NJOP sesuai dengan harga pasar } \\
\text { wajar? }\end{array}$ & Coercive Pressure & $\begin{array}{l}\text { To find out the existence of regulation as } \\
\text { a basis for coercive pressure. }\end{array}$ \\
\hline Q & 4 & $\begin{array}{l}\text { Apa yang menjadi kendala penetapan NJOP yang sesuai } \\
\text { nilai pasar? }\end{array}$ & Internal Perception & $\begin{array}{l}\text { To find out participants' perceptions } \\
\text { about the existing constraints. }\end{array}$ \\
\hline $\mathrm{Q}$ & 5 & $\begin{array}{l}\text { Apakah masyarakat/wajib pajak setuju dengan konsep } \\
\text { NJOP sesuai dengan harga pasar? }\end{array}$ & Normative Pressure & $\begin{array}{l}\text { To know the existence of normative } \\
\text { pressure. }\end{array}$ \\
\hline Q & 6 & $\begin{array}{l}\text { Apakah bentuk dan struktur organisasi mendukung } \\
\text { dalam penetapan NJOP yang wajar? }\end{array}$ & Internal Perception & $\begin{array}{l}\text { To find out participants' perceptions } \\
\text { about the internal conditions of the } \\
\text { organisation. }\end{array}$ \\
\hline Q & 7 & Apakah SDM di BPKAD Yogyakarta sudah mencukupi? & Internal Perception & $\begin{array}{l}\text { To find out participants' perceptions } \\
\text { about the internal conditions of the } \\
\text { organisation. }\end{array}$ \\
\hline Q & 8 & $\begin{array}{l}\text { Apakah ada daerah atau pemda lain yang menjadi acuan } \\
\text { dalam penetapan NJOP di Kota Yogyakarta? }\end{array}$ & Mimetic Pressure & $\begin{array}{l}\text { To know the existence of mimetic } \\
\text { mechanisms. }\end{array}$ \\
\hline Q & 9 & Adakah solusi yang mungkin bisa dilakukan? & Internal Reaction & $\begin{array}{l}\text { To find out the response made in the face } \\
\text { of external pressure. }\end{array}$ \\
\hline Q & 10 & $\begin{array}{l}\text { Apakah menurut anda, permasalah penetapan NJOP } \\
\text { dibawah nilai pasar juga terjadi di wilayah lain? }\end{array}$ & Normative Pressure & $\begin{array}{l}\text { To know the existence of normative } \\
\text { pressure from the surrounding } \\
\text { environment. }\end{array}$ \\
\hline Q & 11 & $\begin{array}{l}\text { Pernahkah anda berdiskusi dengan instansi pemerintah } \\
\text { di wilayah lain mengenai masalah ini? }\end{array}$ & Normative Pressure & $\begin{array}{l}\text { To know the existence of normative } \\
\text { pressure from the surrounding } \\
\text { environment }\end{array}$ \\
\hline Q & 12 & $\begin{array}{l}\text { Apakah ada kemungkinan kedepannya NJOP akan sama } \\
\text { dengan rata-rata nilai pasar secara berkelanjutan? }\end{array}$ & Coercive Pressure & $\begin{array}{l}\text { To find out the future organisational } \\
\text { behavior due to coercive pressure. }\end{array}$ \\
\hline
\end{tabular}

Appendix 2. Interview Transcripts

\begin{tabular}{|c|c|c|}
\hline Code & Translation Transcript & Themes \\
\hline MQ2.1 & Today, March 5, 2020, Thursday with Mr. ... as the Head of Subdivision of Regional Income ... & \\
\hline MR2.1 & $\begin{array}{l}\text { So, here is not only the Land and building tax (LBT) matter but all local taxes, there is no ... In other regions there } \\
\text { may be only the LBT sector, in this case, we run all areas, including determination, hotels, including parking and } \\
\text { LBT, ADRLB. All are ten types of tax objects. }\end{array}$ & \\
\hline MQ2.2 & Sir, this is what I'm asking if the SVTO LBT in your work area matches the price? & \\
\hline MR2.2 & $\begin{array}{l}\text { Inshallah, since this year we are adjusting market prices and we are using ADRLB transaction data reported and } \\
\text { researched by our co-workers, we recorded and based on ADRLB transactions until 2018, then we also use LVZ data } \\
\text { from NLA 2017. Inshallah, if there is a gap, it is just a little. But... yes, as a result, SVTO has jumped to } 400 \text { percent. }\end{array}$ & A4; A1 \\
\hline MQ2.3 & The last appraisal before 2019, What year was it? & \\
\hline MR2.3 & two thousand fourteen or fifteen. So, two thousand fourteen or two thousand fifteen. & \\
\hline MQ2.4 & In your perspective, is SVTO in accordance with market prices something important? & \\
\hline MR2.4 & $\begin{array}{l}\text { So, we have to distinguish between the sales value and the tax. } \\
\text { The selling value should match the market price because the selling price is as a reasonable average price. It is not } \\
\text { only concerned with LBT, but it will also certainly be related to ADRLB. It can also be related later to appraisal for a } \\
\text { building and so on. So, the government... with SVTO, can reflect the prices that occur naturally. So, it is important ... } \\
\text { yes. Even though the selling price is like a series of measurements with a series of rows, it is still worth to be true. } \\
\text { So, I think it's important. }\end{array}$ & $\mathrm{A} 2$ \\
\hline MQ2.5 & $\begin{array}{l}\text { Is there any regulation in the city of Jogja like the mayor decree that mandates SVTO in accordance with the market } \\
\text { prices? }\end{array}$ & \\
\hline MR2.5 & $\begin{array}{l}\text { So, even in the law, by regulations, it has been mandated to use zones ... What ... Every three years we set SVTO, it } \\
\text { means that we set SVTO to match with the market price ... existing LVZ. Yes, implicitly there is. Later it is called ... }\end{array}$ & A7 \\
\hline
\end{tabular}




\begin{tabular}{|c|c|c|}
\hline Code & Translation Transcript & Themes \\
\hline & $\begin{array}{l}\text { there was mayor decree number } 9 \text { of 2014, mayor decree of } 91 \text { or ... } 91 \text { of } 2014 \text {, I guess ... that was about the } \\
\text { procedures for ... SVTO, there was a mayor decree in } 2014 \text { which was already published. }\end{array}$ & \\
\hline MQ2.6 & In your opinion, what obstacles are often faced in determining SVTO according to market prices? & \\
\hline MR2.6 & $\begin{array}{l}\text { Well, yes this is ... the main obstacle is our awareness of both government agencies, which in this case determines } \\
\text { LBT and communities because of what ... awareness of SVTO has many aspects ... awareness for us to determine } \\
\text { market prices and to the determination of tax. For the community, SVTO, that means... yes they also need to, } \\
\text { someday if there is a transaction, for the matter of collateral, bank uses SVTO as well. So, SVTO awareness should } \\
\text { be of all parties ... Because with SVTO that is in line with market prices, there is no need to be bothered with an } \\
\text { appraisal matter. So, it can be said if in case of hotels, even when SVTO goes up, it actually raises their assets as } \\
\text { well ... so that with a reasonable SVTO actually helps, everyone. It is important, the most important obstacle is } \\
\text { awareness, then the second obstacle is related to the rules. This means, ok, SVTO may be the same as the market } \\
\text { [price] but people are actually afraid of the tax levied. So, it can be responded to, for example, a high SVTO because } \\
\text { of the market price, then how about the policies of each government, for example, in Jakarta it is not taxed for } \\
\text { particular billion, it helps marginal people. The amount of UVSVTO depends on the ability of the region or maybe } \\
\text { the other tariffs are mentioned in the Laws at the maximum of } 0.3 \text { percent, there are regions that can use } 0.0 \\
\text { percent, depending on the ability of the individual subjects. But, the object must be matched with the market price ... } \\
\text { an object is a dead matter ... can't say anything... assessment conducted by persons ... that means, it should be like } \\
\text { that, so each one's awareness ... and then when it is used for taxation, there must be a policy that can satisfy } \\
\text { everyone. }\end{array}$ & \\
\hline MQ2.7 & Those are the constraints? & \\
\hline MR2.7 & $\begin{array}{l}\text { Moreover, there is another constraint, we openly say to the local governments, almost all regions ... we have never } \\
\text { had the reliable appraisers. That is the most important, human resources have not been like.... when it is managed by } \\
\text { the tax office ... they already have experts. Now just try to check, of the six hundred tier-two governments, how } \\
\text { many appraisers are required? Only a few cities have it. Jogja uses a team for appraising, so we use a team that is } \\
\text { filled by employees or personnel who have been trained in Jakarta related to ... LBT valuation. } \\
\text { But, functionally there is no functional LBT appraiser, the SVTO Appraiser, in essence. So, the next factor is the } \\
\text { absence of appraisers. } \\
\text { Besides, yes, God willing, infrastructure, for example, involving NLA and LVZ. related to equipment, maybe, yes ... } \\
\text { reasonable but most importantly also, from us, we do not have sufficient human resources. }\end{array}$ & A6; A5 \\
\hline MQ2.8 & If there are no functional officers to be appraisers, how many people have been trained, Sir? & \\
\hline MR2.8 & $\begin{array}{l}\text { There are eight, eight... there are Meka, Fajar, Kunti, Maemun, Devinta, Romadhon, and then Meka and Anita ... } \\
\text { eight, eight people. But that's not sufficient ... need D1, D2... you know, it's just a kind of training from the Ministry } \\
\text { of Finance or STAN, you know ... Not yet ... there hasn't been a diploma but only training for one month and two } \\
\text { months. Yes, some kind of technical training or the same ... But what we need is minimal D1, D2, you know. so } \\
\text { "nglothok" (expert) is the slang... }\end{array}$ & A6 \\
\hline MQ2.9 & Has BPKAD conducted in-house training yet, Sir? & \\
\hline MR2.9 & $\begin{array}{l}\text { Yes, it has been done ... in-house training has been done from those who have delivered their expertise to those who } \\
\text { have not yet experienced. Yes, it has been done, but the capability still needs to be developed. There, really need a } \\
\text { graduated appraiser who really has the certificate, you know. It's compatible. At least D1 then upgraded to D2 ... we } \\
\text { don't have one yet, and we have also collaborated with STPN, they offer to do calculations and so on, we just try to } \\
\text { be like that. Then, Bappeda conducts a study, like that, it is clear that we don't have that appraiser... . }\end{array}$ & A6 \\
\hline MQ2.10 & Have you asked STAN Sir, about the possibility to open class for the appraiser? & \\
\hline MR2.10 & $\begin{array}{l}\text { If it is education and training, it hasn't been done until } 1 \text { year and } 2 \text { years, Sir. Just training for up to } 6 \text { months. Yes, } \\
\text { we sent it and just it. I do not know maybe God willing if indeed there is a course opened for the regional } \\
\text { employees, that special education... either at STAN or at UGM, UI and so on specifically for D1 appraisal. We have } \\
\text { also frankly conveyed to BKPP, to the Personnel Agency to propose employees to be sent to school. The problem is } \\
\text { that if we are the ones who can participate in D1, who can be financed is only a-high-school-graduated person, for } \\
\text { those of us who have secured the bachelor degree ... you know ... what is it ... but it should be regulated by a mayor } \\
\text { decree or how about even though D1 is taught it's not a problem, you know ... the obstacle is the regulation factor. }\end{array}$ & \\
\hline MQ2.11 & $\begin{array}{l}\text { The issues involving community and taxpayer, do you think the community agrees with the concept of SVTO in line } \\
\text { with market values? }\end{array}$ & \\
\hline MR2.11 & $\begin{array}{l}\text { Automatically they do not (agree SVTO close to market price), sure ... at least, but we divide it, first because they } \\
\text { don't know for the importance of SVTO, the second they really don't want to. Because they usually have land not } \\
\text { only in Jogja but everywhere, you know, they don't want to. But for people who need SVTO, when they want to } \\
\text { apply debt to the bank, they need SVTO or for an entity, they don't mind because of what? It will increase the value } \\
\text { of their assets. Just check on it, on the report, there is a balance sheet, it will be reported, so they do not need to use } \\
\text { appraisal, just using SVTO, asset values will go up by itself ... yes, if you may every year ... go up without our } \\
\text { concern because SVTO goes up ... that means that there are two choices, In general, because this society is more } \\
\text { heterogeneous. Most of them think that the most important is not paying taxes ... if tax levied is lower, they even } \\
\text { don't care about it ... that is important, a low tax ... it must be ... about SVTO, they also do not pay much attention, } \\
\text { rarely pay attention. }\end{array}$ & A2 \\
\hline MQ2.12 & So if the tax is low the people don't ... (cut) & \\
\hline MR2.12 & No problem, sure ... No problem & \\
\hline MQ2.13 & The problem is because when SVTO increase triggers its tax? & \\
\hline MR2.13 & $\begin{array}{l}\text { Nah ... So there must be a formula, how the tax does not go up, for example UVSVTO also rises, so when SVTO } \\
\text { rises UVSVTO is increased, then the tariff is reduced ... just like that ... }\end{array}$ & \\
\hline MQ2.14 & $\begin{array}{l}\text { e, Sir, does or does not the form of organisation, organisational structure and information } \\
\text { t, according to your opinion? }\end{array}$ & \\
\hline
\end{tabular}




\begin{tabular}{|c|c|c|}
\hline Code & Translation Transcript & Themes \\
\hline MR2.14 & $\begin{array}{l}\text { Related to this SVTO? So, we at the municipal government, actually at the last time, we were greatly assisted by } \\
\text { Department of Communication and Information. They informed the community and all employees in the municipal } \\
\text { government. So, there was already an institution that delivered related to the increasing SVTO. The problem is that } \\
\text { the delivery was sometimes too late, as long as in this sense, when ... like we receive SPPT, we rarely see the basis } \\
\text { for the tax imposition, the only important thing is the tax. So, when the SVTO increases, the attention is to the tax } \\
\text { paid instead of to the SVTO. }\end{array}$ & \\
\hline MQ2.15 & About the form of the organisation, the readiness of the organisation, is it good, Sir? & \\
\hline MR2.15 & $\begin{array}{l}\text { So here we are, so as you said, our organisational form does not yet differentiate the LBT itself ... well, that is one of } \\
\text { the real obstacles, so the information is conveyed less quickly. So, structurally this organisation, in my opinion, my } \\
\text { perspective ... that's not quite right. must be distinguished ... the central, the department ... the department of LBT } \\
\text { and ADRLB itself, other departments because of their different nature. So, it's still not good, Sir. still not good ... in } \\
\text { my opinion ... it's not good enough. }\end{array}$ & A3 \\
\hline MQ2.16 & About SISMIOP, DBKB, GIS, is the information system sufficient, Sir? & \\
\hline MR2.16 & $\begin{array}{l}\text { So far, we have received it from the center, yes, we have developed it, Sir, so we have developed SISMIOP ... we } \\
\text { have developed it and we have used the data up to now, and we are still using it and it is still sufficient. we don't } \\
\text { think of using other systems. Except later when it's broken and so on ... new ... Because we are still ... we already } \\
\text { have experts. }\end{array}$ & A5 \\
\hline MQ2.17 & $\begin{array}{l}\text { In SVTO assessment Sir, the determination according to market prices, does Jogja have a reference region or a } \\
\text { comparative study place, a place of study for ... "Oh, I follow this determination process like that region"? }\end{array}$ & \\
\hline MR2.17 & $\begin{array}{l}\text { Ya ... Sometimes, in many years we also learn too. automatically, learning ... We have also studied at DKI, studied at } \\
\text { Badung in Bali. But then we don't ... "plek" ... we also definitely learn Mas. no, if we don't learn, but then it is } \\
\text { adjusted to our condition, if we don't have an appraisal staff, we use LVZ which has been assessed by experts from } \\
\text { NLA. Plus, at self-reported prices, with the ADRLB. So we can do it Sir, Insha Allah we can. But still, we use a } \\
\text { comparative study even though from many years ago. Just like that. Knowledge is always needed. }\end{array}$ & A9 \\
\hline MQ2.18 & When was the last comparative study, Sir? & \\
\hline MR2.18 & $\begin{array}{l}\text { Last time, we even went to UGM to ask (laugh) ... Last time ... Here you know, the funny thing is there are lots of } \\
\text { friends from outside the area who, from either Jakarta, Bandung came to Jogja. We ask back, we don't have to go } \\
\text { there ... Just ask ... So that's it, so we ask a lot of their working visits persons, because we are selective, Sir. This year } \\
\text { we also have no comparative visit, except for an official meeting. Even if there is a study visit, it is just to UGM. The } \\
\text { last was to Solo ... that's it. But it was already two years ago, at UGM was last year. }\end{array}$ & \\
\hline MQ2.19 & $\begin{array}{l}\text { The increase in the current SVTO Sir, is there an increase in the submission of a reduction or can it be said as a } \\
\text { protest from the community or NGOs to your agency? }\end{array}$ & \\
\hline MR2.19 & $\begin{array}{l}\text { Up to now, there have been around } 400 \text { reductions, only two months there have been four hundred, whereas last } \\
\text { time there were only about a thousand deductions. it's going to go up by about four times ... Possibly ... Possibly, } \\
\text { because of the opening of a wider reduction tap, if previously only veterans, retired, retired civil servants were then } \\
\text { the poor with a pre-prosperous card, KMS, now opened ... everyone can apply with a statement letter of not being } \\
\text { able to pay taxes, So, It is expected to go up more. There was a protest from the public, we conducted counseling, } \\
\text { we were socialising, we wondered why it was up and reaching with regard to taxes, they could propose a reduction. } \\
\text { there is... if there is no frontal protest. Yes indeed, it was explained like this ... The important thing for the } \\
\text { community is that the tax does not go up (laughs) }\end{array}$ & \\
\hline MQ2.20 & In your perspective, the problem of SVTO under the market price is found in other regions or districts or not, Sir? & \\
\hline MR2.20 & $\begin{array}{l}\text { Wah, it's not ethical if I answer ... There certainly is, I don't want to answer this. You know for yourself ... There are } \\
\ldots \text { in DIY which one is approaching the market prices? Just check out of all } 5 \text { regions which is the closest. I do not } \\
\text { need to mention ... Just feel free to check yourself if that (laugh) ... it's not ethical... }\end{array}$ & \\
\hline MQ2.21 & Have you ever discussed with outside agencies or other cities about this issue and sought solutions, Sir? & \\
\hline MR2.21 & $\begin{array}{l}\text { Yes ... We do it every few months, periodically, there is an income department communication forum. Revenue service } \\
\text { throughout DIY. We have brought from friends from Pratama to deliver ... We discussed how to determine SVTO, but } \\
\text { yes it is ... what matters ... conveying to each other, this is how to raise... It was conveyer the easiest way, using LVZ by } \\
\text { NLA. but please check by yourself, which one has already used. Even though, last year we had a discussion ... but please } \\
\ldots \text { because for many regions, peaceful agenda is important. But later the effect is... the effect is, Sir, if we do not keep } \\
\text { up with the market price, we will lag behind. the more it will go up, the more time bombs. }\end{array}$ & A8 \\
\hline MQ2.22 & According to you, why can other regions not implement the strategies carried out by the city of Yogyakarta Sir? & \\
\hline MR2.22 & I don't know straight out (laughs) ... I don't dare to answer it & \\
\hline MQ2.23 & Is it about internal factors? & \\
\hline MR2.23 & $\begin{array}{l}\text { I don't know ...I don't dare to answer it ... Probably you ... You already know the answer (laugh) ... I don't want to } \\
\text { answer, you already know the answer ... The agenda behind it ... up to you ... (laugh) }\end{array}$ & \\
\hline MQ2.24 & $\begin{array}{l}\text { This is the last question and to emphasise Sir, according to you, SVTO of the city of Jogja whether close to market } \\
\text { prices or not yet? }\end{array}$ & \\
\hline MR2.24 & $\begin{array}{l}\text { God willing, SVTO is approaching the market price because we record it from transactions that occur in ADRLB and } \\
\text { LVZ obtained from other agencies that are indeed competent. God willing, although the market price will still } \\
\text { continue to rise. God willing, it is getting closer. It's not exactly the same as the market price, but it's OK, God } \\
\text { Willing, it is approaching. we've checked it anyway. }\end{array}$ & A1 \\
\hline MQ2.25 & Thank you for your time, Sir & \\
\hline MR2.25 & You are welcome & \\
\hline
\end{tabular}


Appendix 3. Recapitulation of General Sense of information

\begin{tabular}{|c|c|c|}
\hline Code & Themes & General Sense of Information \\
\hline \multirow{2}{*}{ A1 } & \multirow{2}{*}{ Current SVTO level } & There are differences in SVTO levels in several regions \\
\hline & & SVTO can be close to market prices or still far below \\
\hline \multirow[b]{2}{*}{ A2 } & \multirow{2}{*}{ Perspective on SVTO } & $\begin{array}{l}\text { SVTO according to market prices mandated by law. Officers should have the same } \\
\text { perception on the importance of carrying out these provisions. }\end{array}$ \\
\hline & & $\begin{array}{l}\text { Taxpayers may have different perceptions about the importance of SVTO according to } \\
\text { market prices. }\end{array}$ \\
\hline A3 & $\begin{array}{l}\text { Organisational } \\
\text { Structure }\end{array}$ & $\begin{array}{l}\text { To establish SVTO according to market prices requires a supportive organisational } \\
\text { structure. }\end{array}$ \\
\hline \multirow[b]{2}{*}{ A4 } & \multirow{2}{*}{ Policies } & Local governments have different policies in establishing SVTO \\
\hline & & Policies taken can be following regulations but can also be different from regulations \\
\hline \multirow[t]{2}{*}{ A5 } & \multirow{2}{*}{$\begin{array}{l}\text { Organisational } \\
\text { Infrastructure }\end{array}$} & $\begin{array}{l}\text { The organisational infrastructure supports the performance of officers in establishing } \\
\text { SVTO. }\end{array}$ \\
\hline & & The information system used is still a legacy from DGT. \\
\hline \multirow{2}{*}{ A6 } & \multirow{2}{*}{ Human resources } & The influences of the number and quality of employees on the process of determining SVTO \\
\hline & & The quantity and quality of employees among regions can be varied. \\
\hline \multirow{2}{*}{ A7 } & \multirow{2}{*}{ Regulations } & $\begin{array}{l}\text { The determination of SVTO according to market prices is mandated by law. Local } \\
\text { governments should also establish harmonious local regulations. }\end{array}$ \\
\hline & & $\begin{array}{l}\text { Regional regulations governing SVTO determination following the law need to be } \\
\text { implemented by local authorities. }\end{array}$ \\
\hline $\mathrm{A} 8$ & Normative & There are local governments that have not practiced SVTO according to market prices. \\
\hline \multirow{2}{*}{ A9 } & \multirow{2}{*}{$\begin{array}{l}\text { Best Practice and } \\
\text { References }\end{array}$} & There is a region as a place for comparative studies. \\
\hline & & Each region has different characteristics that are difficult to compare. \\
\hline \multirow{2}{*}{ A10 } & \multirow{2}{*}{$\begin{array}{l}\text { Obstacles on } \\
\text { Determination }\end{array}$} & In determining SVTO according to market prices, there are obstacles faced by officers. \\
\hline & & The existing obstacles are from the internal and external sides. \\
\hline
\end{tabular}

Appendix 4. Recapitulation Themes and Sub-themes

\begin{tabular}{|c|c|c|c|}
\hline Code & Themes & Sub-themes & $\begin{array}{l}\text { Sub-Themes } \\
\text { code }\end{array}$ \\
\hline \multirow[b]{2}{*}{ A1 } & \multirow{2}{*}{ Current SVTO level } & Far from the market price & $\mathrm{A} 1_{\mathrm{a}}$ \\
\hline & & Close to market price & $\mathrm{A} 1_{\mathrm{b}}$ \\
\hline \multirow{5}{*}{ A2 } & \multirow{5}{*}{ Perspective on SVTO } & By Officer: Market price is important & $\mathrm{A} 2_{\mathrm{a}}$ \\
\hline & & By Officer: Market price is not important & $\mathrm{A} 2_{\mathrm{b}}$ \\
\hline & & Public agreement: Market price is important & $\mathrm{A} 2_{\mathrm{c}}$ \\
\hline & & Public disagreement: Market price is important & $\mathrm{A} 2_{\mathrm{d}}$ \\
\hline & & Pros and Cons & $\mathrm{A} 2_{\mathrm{e}}$ \\
\hline \multirow{2}{*}{$\mathrm{A} 3$} & \multirow{2}{*}{$\begin{array}{l}\text { Organisational } \\
\text { Structure }\end{array}$} & Adequate & $\mathrm{A} 3_{\mathrm{a}}$ \\
\hline & & Inadequate & $A 3_{b}$ \\
\hline \multirow{2}{*}{ A4 } & \multirow{2}{*}{ Policies } & Catching up with the market price & $\mathrm{A} 4_{\mathrm{a}}$ \\
\hline & & Slow and steady & $\mathrm{A} 4_{\mathrm{b}}$ \\
\hline \multirow{2}{*}{ A5 } & \multirow{2}{*}{$\begin{array}{l}\text { Organisational } \\
\text { Infrastructure }\end{array}$} & Sufficient & $\mathrm{A} 5_{\mathrm{a}}$ \\
\hline & & Insufficient & $\mathrm{A} 5_{\mathrm{b}}$ \\
\hline \multirow{4}{*}{ A6 } & \multirow{4}{*}{ Human resources } & Sufficient in quantity & $\mathrm{A} 6_{\mathrm{a}}$ \\
\hline & & Insufficient in quantity & $A 6_{b}$ \\
\hline & & Sufficient in quality & $\mathrm{A} 6_{\mathrm{c}}$ \\
\hline & & Insufficient in quality & $A 6_{d}$ \\
\hline \multirow{4}{*}{ A7 } & \multirow{4}{*}{ Regulations } & regulated in regional regulations & $\mathrm{A} 7 \mathrm{a}$ \\
\hline & & not regulated in regional regulations & $\mathrm{A} 7_{\mathrm{b}}$ \\
\hline & & Implementing regional regulations & $\mathrm{A} 7_{\mathrm{c}}$ \\
\hline & & not yet implementing regulations & $\mathrm{A} 7_{\mathrm{d}}$ \\
\hline \multirow{2}{*}{ A8 } & \multirow{2}{*}{ Normative } & Other regions are practicing SVTO close the market price. & $A 8_{a}$ \\
\hline & & Other regions are not practicing SVTO close to market & $\mathrm{A} 8_{\mathrm{b}}$ \\
\hline \multirow{3}{*}{ A9 } & \multirow{3}{*}{$\begin{array}{l}\text { Best Practice and } \\
\text { References }\end{array}$} & Existent & $\mathrm{A} 9_{\mathrm{a}}$ \\
\hline & & Inexistent & $\mathrm{A} 9_{\mathrm{b}}$ \\
\hline & & Cannot imitate Jogja's strategy & $\mathrm{A} 9_{\mathrm{c}}$ \\
\hline \multirow{6}{*}{ A10 } & \multirow{6}{*}{$\begin{array}{l}\text { Obstacles on } \\
\text { Determination }\end{array}$} & Validity of Data & $\mathrm{A} 10_{\mathrm{a}}$ \\
\hline & & Geographical issue & $\mathrm{A} 10_{\mathrm{b}}$ \\
\hline & & Mapping and Zoning & $\mathrm{A} 10_{\mathrm{c}}$ \\
\hline & & Protest from public & $\mathrm{A} 10_{\mathrm{d}}$ \\
\hline & & Increasing property tax levied & $\mathrm{A} 10_{\mathrm{e}}$ \\
\hline & & Cultural and Educational level & $\mathrm{A} 10_{\mathrm{f}}$ \\
\hline
\end{tabular}


Appendix 5. Tabulation of Themes and Sub-themes of Participants

\begin{tabular}{|c|c|c|c|c|c|c|c|c|c|c|c|c|}
\hline \multirow[b]{2}{*}{ Themes } & \multirow[b]{2}{*}{ Sub-themes } & \multirow{2}{*}{$\begin{array}{l}\text { Sub- } \\
\text { Themes } \\
\text { code }\end{array}$} & \multicolumn{5}{|c|}{ BPKAD Yogyakarta } & \multicolumn{5}{|c|}{ BKAD Bantul } \\
\hline & & & MR1 & MR2 & MR3 & MR4 & MR5 & MR6 & MR7 & MR8 & MR9 & MR10 \\
\hline \multirow{2}{*}{$\begin{array}{l}\text { Current NJOP } \\
\text { level }\end{array}$} & Far from market price & $\mathrm{A} 1_{\mathrm{a}}$ & & & & & & MR6.1 & MR7.1 & MR8.1 & MR9.1 & MR10.1 \\
\hline & Close to market price & $\mathrm{A} 1_{\mathrm{b}}$ & MR1.1 & MR2.2 & MR3.1 & MR4.1 & MR5.1 & & & & & \\
\hline \multirow{5}{*}{$\begin{array}{l}\text { Perspects of } \\
\text { NJOP }\end{array}$} & $\begin{array}{l}\text { By Officer: Market } \\
\text { price is important }\end{array}$ & $\mathrm{A} 2 \mathrm{a}_{\mathrm{a}}$ & & MR2.4 & MR3.3 & MR4.4 & MR5.2 & MR6.2 & MR7.2 & MR8.2 & MR9.3 & MR10.3 \\
\hline & $\begin{array}{l}\text { By Officer: Market } \\
\text { price is not important }\end{array}$ & $\mathrm{A} 2_{\mathrm{b}}$ & & & & & & & & & & \\
\hline & $\begin{array}{l}\text { Public agreement: } \\
\text { Market price is } \\
\text { important }\end{array}$ & $\mathrm{A} 2 \mathrm{c}$ & & & & & & MR6.6 & & & & \\
\hline & $\begin{array}{l}\text { Public disagreement: } \\
\text { Market price is } \\
\text { important }\end{array}$ & $\mathrm{A} 22_{\mathrm{d}}$ & & MR2.11 & & & MR5.6 & & MR7.6 & & & MR10.7 \\
\hline & Pros and Cons & $\mathrm{A} 22_{\mathrm{e}}$ & & & MR3.8 & MR4.7 & & & & MR8.5 & MR9.9 & \\
\hline \multirow{2}{*}{$\begin{array}{l}\text { Organisational } \\
\text { Structure }\end{array}$} & Adequate & $\mathrm{A} 3_{\mathrm{a}}$ & MR1.5 & & MR3.11 & MR4.8 & & MR6.9 & & & MR9.11 & \\
\hline & Inadequate & $\mathrm{A} 3_{\mathrm{b}}$ & & MR2.15 & & & & & & & & \\
\hline \multirow[t]{2}{*}{ Policies } & $\begin{array}{l}\text { Catching up the market } \\
\text { price }\end{array}$ & $\mathrm{A} 44_{\mathrm{a}}$ & & MR2.2 & MR3.4 & MR4.1 & MR5.16 & & & & & \\
\hline & Slow and steady & $\mathrm{A} 4_{\mathrm{b}}$ & & & & & & MR6.7 & MR7.1 & MR8.3 & MR9.15 & MR10.19 \\
\hline \multirow{3}{*}{$\begin{array}{l}\text { Organisational } \\
\text { Infrastructure }\end{array}$} & Sufficient & $\mathrm{A} 5_{\mathrm{a}}$ & & MR2.16 & & MR4.10 & & & & & & MR10.10 \\
\hline & Insufficient & $A 5_{b}$ & & & MR3.11 & & & & & MR8.7 & & \\
\hline & Sufficient in quantity & $\mathrm{A} 6_{\mathrm{a}}$ & MR1.6 & & & & & & & & & \\
\hline \multirow{3}{*}{$\begin{array}{l}\text { Human } \\
\text { resources }\end{array}$} & Insufficient in quantity & $A 6_{b}$ & & & MR3.12 & & MR5.7 & MR6.12 & MR7.11 & MR8.9 & MR9.12 & MR10.15 \\
\hline & Sufficient in quality & $\mathrm{A} 6_{\mathrm{c}}$ & & & & & MR5.7 & & & MR8.9 & & \\
\hline & Insufficient in quality & $A 6_{d}$ & & MR2.7 & & MR4.11 & & & MR7.7 & & MR9.11 & MR10.16 \\
\hline \multirow{4}{*}{ Regulations } & $\begin{array}{l}\text { regulated in regional } \\
\text { regulations }\end{array}$ & $\mathrm{A} 7 \mathrm{a}$ & MR1.3 & MR2.5 & MR3.5 & MR4.5 & MR5.3 & MR6.3 & MR7.3 & & & \\
\hline & $\begin{array}{l}\text { not regulated in } \\
\text { regional regulations }\end{array}$ & $\mathrm{A} 7_{\mathrm{b}}$ & & & & & & & & MR8.3 & & \\
\hline & $\begin{array}{l}\text { Implementing regional } \\
\text { regulations }\end{array}$ & $\mathrm{A} 7 \mathrm{c}$ & MR1.2 & MR2.5 & & MR4.5 & MR5.4 & & & & & \\
\hline & $\begin{array}{l}\text { not yet implementing } \\
\text { regulations }\end{array}$ & $\mathrm{A} 7_{\mathrm{d}}$ & & & & & & MR6.7 & & & & \\
\hline \multirow{2}{*}{ Normative } & $\begin{array}{l}\text { Other regions are } \\
\text { practising NJOP close } \\
\text { to the market price }\end{array}$ & $\mathrm{A} 8 \mathrm{a}$ & & & & & & & & & & \\
\hline & $\begin{array}{l}\text { Other regions are not } \\
\text { practising NJOP close } \\
\text { to the market price }\end{array}$ & $\mathrm{A} 8_{\mathrm{b}}$ & & MR2.20 & MR3.22 & & MR5.13 & MR6.23 & MR7.14 & MR8.14 & MR9.13 & MR10.20 \\
\hline \multirow{3}{*}{$\begin{array}{l}\text { Best Practice } \\
\text { and } \\
\text { References }\end{array}$} & Existent & $\mathrm{A} 9_{\mathrm{a}}$ & & MR2.17 & MR3.16 & & & MR6.16 & & & & \\
\hline & Inexistent & $A 9 b$ & MR1.8 & & & MR4.15 & MR5.9 & & & MR8.11 & MR9.13 & \\
\hline & $\begin{array}{l}\text { Cannot imitate Jogja's } \\
\text { strategy }\end{array}$ & $\mathrm{A} 9 \mathrm{c}$ & & & & & & MR6.15 & MR7.15 & MR8.12 & MR9.16 & MR10.13 \\
\hline \multirow{6}{*}{$\begin{array}{l}\text { Obstacles on } \\
\text { Determination }\end{array}$} & Validity of Data & $\mathrm{A} 10_{\mathrm{a}}$ & MR1.10 & & MR3.21 & & & & MR7.5 & MR8.4 & MR9.1 & \\
\hline & Geographical issue & $\mathrm{A} 10_{\mathrm{b}}$ & & & & & & & MR7.15 & MR8.6 & & \\
\hline & Mapping and Zoning & $\mathrm{A} 10_{\mathrm{c}}$ & & & & & & MR6.15 & & MR8.6 & & MR10.6 \\
\hline & Protest from public & $\mathrm{A} 10_{d}$ & & & & & MR5.5 & MR6.5 & & MR8.13 & MR9.16 & \\
\hline & Increasing property tax & $\mathrm{A} 10_{\mathrm{e}}$ & & & & MR4.6 & MR5.5 & MR6.5 & MR7.2 & MR8.12 & & MR10.3 \\
\hline & $\begin{array}{l}\text { Cultural and } \\
\text { Educational level }\end{array}$ & $\mathrm{A} 10_{\mathrm{f}}$ & & & & & & & MR7.15 & & & \\
\hline
\end{tabular}

